Bulletin of Pharmaceutical_Sciences
Assiut University

\title{
NARINGIN PREVENT CISPLATIN-INDUCED NEPHROTOXICITY BY ABROGATION OF OXIDATIVE STRESS AND INFLAMMATION IN RATS
}

\author{
Abd-Elmoniem A. Taha ${ }^{2}$, M. M. A. Khalifa ${ }^{1 *}$ and Mohamed I. Abd El-Salam ${ }^{2}$ \\ ${ }^{1}$ Department of Pharmacology and Toxicology, Faculty of Pharmacy, Minia University, Egypt \\ ${ }^{2}$ Department of Pharmacology and Toxicology, Faculty of Pharmacy, Al-Azhar University, \\ Assiut, Egypt
}

\begin{abstract}
Nephrotoxicity remains one of the most dangerous effect relevant to cisplatin use in chemotherapy. Rat injection with cisplatin in a single dose of $7 \mathrm{mg} / \mathrm{kg}$ intraperitoneally resulted in a significant increase in serum level of urea and creatinine. Also, cisplatin caused marked increase in renal content of malondialdehyde (MDA), while depletion in reduced glutathione (GSH). In addition, cisplatin administration notably increased kidney/body weight ratio, renal contents of nitric oxide (NO), tumor necrosis factor alpha(TNF- $\alpha)$ and cyclooxygenase-2 (COX2) protein level as well as renal myeloperoxidase (MPO) activity. Histopathological examination confirmed the biochemical and molecular results which revealed several pathological alteration in the renal tissues following cisplatin. Oral pretreatment of rats with naringin (NAR) $(80 \mathrm{mg} / \mathrm{kg})$ for 14 days before and 7 days after cisplatin injection significantly reduced the pathological level of serum urea and creatinine and restored oxidative stress parameters. In the same manner, the inflammatory markers as well as kidney/body weight ratio show great improvement following the treatment. The histopathological examination confirms fit with the biochemical and molecular results. In conclusion, NAR showed a great protective effect against cisplatin-induced nephrotoxicity in rats via its antioxidant, anti-inflammatory roles.
\end{abstract}

\section{INTRODUCTION}

The kidneys are the most organ concerning with drug elimination. Approximately $90 \%$ of drug excreted mainly by the kidneys ${ }^{1-3}$. Acute kidney injury (AKI) one of the most complicated factor of chemotherapy use against human malignancies hence, drugs induced renal toxicity remains the most problems that limit the beneficial roles of chemotherapeutic agents ${ }^{4}$. Cisplatin (CP) is a key chemotherapeutic drug used in the treatment of many solid tumors and hematological malignancies 5 . Unfortunately, $\mathrm{CP}$ cannot effectively differentiate healthy cells from malignant cells; as a result, it accumulates in healthy tissues, leading to severe clinical toxicities in different body organs, including kidneys as the kidney is the main route of excretion of $\mathrm{CP}^{6}$. Tubular cell injury occurs in one third of $\mathrm{CP}$ treated patients and manifests as an increase in serum creatinine and urea concentration as well as imbalanced electrolytes, which limits its use as chemotherapeutic agents. Although, intense efforts over the past decades to find less toxic, but equally effective alternatives, $\mathrm{CP}$ continues to be widely prescribed ${ }^{7 \& 8}$.

It was postulated that CP-induced nephrotoxicity was mediated through the generation of large amount of reactive oxygen species (ROS), which induces lipid peroxidation, the oxidative damage in renal cells, increase renal capillary permeability and tubular atrophy ${ }^{9 \& 10}$. As, overproduction of ROS causes activation of oxidative stress cascade and depletion of endogenous antioxidants, that trigger an immune response and mediate

Received in 26/4/2018 \& Accepted in 30/4/2018 
inflammation. This inflammation is characterized by overproduction and activation of pro-inflammatory cytokines such as tumor necrosis factor-alpha (TNF- $\alpha$ ), nitric oxide (NO) and inflammatory cell infiltration. Additionally, CP induces apoptosis and necrosis of renal tubular cells through activation of both intrinsic and extrinsic mitochondrial pathways as well as its direct tubular toxicity ${ }^{1112}$. Several strategies applied dosage optimization, the use of analogues or combined therapy, and many other trials have been done to attenuate $\mathrm{CP}$ side effects but no promising results have been achieved.

Thus, there is a need for identifying alternative, natural, and safer sources capable of protecting the cells from oxidative injury, as herbal extracts which, possess many properties such as antioxidant, anti-inflammatory, antiproliferative, and anticarcinogenicity.

Naringin (Nar) is a flavanone glycoside, isolated from the grape and citrus fruit species $^{13 \& 14}$. The therapeutic activity of NAR has been reported to possess biological and pharmacological properties including anticarcinogenic, lipid-lowering, ant apoptotic, anti-atherogenic, metal chelating and antioxidant activities. Furthermore, another animal study reported that NAR has antiinflammatory effects both in vitro and in vivo by modulating of the expression of TNF- $\alpha$, interleukin-6 (IL-6), interleukin-8 (IL-8) and inducible Nitric oxide synthase (iNOS). Also, it was reported that NAR has potent antioxidant properties via abrogation of oxidative stress and high free radical scavenging activity ${ }^{15-17}$.

Therefore, the current study was done to investigate the possible nephroprotective effect of NAR against CP-induced nephrotoxicity in rats.

\section{MATERIALS AND METHODS}

\section{Drugs and chemicals}

Cisplatin was obtained from MYLAN United Pharmaceuticals Co. , Egypt, and given i. p. in a single dose of $7 \mathrm{mg} / \mathrm{kg}^{18}$. NAR was purchased from Sigma-Aldrich (Seeize, Germany) and given orally in a dose of 80 $\mathrm{mg} / \mathrm{kg}$ daily for 14 days before $\mathrm{CP}$ injection and for 7 days after CP injection ${ }^{19}$. Elman's reagent, thiobarbituric acid, (GSH), 1,1,3,3tetramethoxypropane,

$\mathrm{N}-(1-\mathrm{Naphthyl})$ ethylenediamine dihydro chloride and trichloroacetic acid were purchased from Sigma-Aldrich (St. Louis, MO). All other chemicals were obtained from local sources with highest analytical grade.

\section{Animals}

Male Swiss albino rats weighing 200-230 $\mathrm{g}$ were housed in the animal house of the Faculty of Medicine, Assiut University. The animals were kept one week to adapt with the environmental conditions. Rats were fed a standard diet and allowed freely accessed to water. Experiment was carried out according to the accepted guidelines for animal care ${ }^{20 .}$

\section{Experimental design}

Twenty four male adult Swiss albino rats were allocated into three groups (eight rats each); two rats from each group were used for histopathological examination as follows:

Group 1: Received saline orally and served as controls.

Group 2: Received CP in a single dose of 7 $\mathrm{mg} / \mathrm{kg}$ i. $\mathrm{p}$.

Group 3: Pretreated with NAR in a daily dose of $80 \mathrm{mg} / \mathrm{kg} \mathrm{p}$. o. for 14 consecutive days and NAR in a daily dose of 80 $\mathrm{mg} / \mathrm{kg}$, p.o. for 7 consecutive days after CP injection.

\section{Serum and tissue preparation}

At the end of the experiment, rats were anesthetized with ketamine $(50 \mathrm{mg} / \mathrm{kg})$ and xylazine $(10 \mathrm{mg} / \mathrm{kg})$ by i. p. , injection, blood samples were withdrawn by a direct cardiac puncture. Sera were collected in nonheparinized tubes and separated by centrifugation for $20 \mathrm{~min}$ at $4000 \times \mathrm{g}$ and stored at $-20^{\circ} \mathrm{C}$ till the time of assay.

The kidneys were rapidly isolated, washed with ice-cold isotonic saline $(0.9 \%)$ and divided into two portions the first portion was stored at $10 \%$ neutral buffered formalin solution and was subjected to histopathological examinations. The second portion was homogenized (20\%) with (Cole-Parmer instrument company, USA) in cold phosphate buffered saline. Tissue homogenates were centrifuged at $3000 \mathrm{rpm}$ for $15 \mathrm{~min}$ at $4^{\circ} \mathrm{C}$. The supernatant was collected, divided into aliquots and stored at $-80^{\circ} \mathrm{C}$ for evaluation of oxidative stress and inflammatory parameters. 


\section{Biochemical analysis}

Assessment of kidney function testes

Serum urea and creatinine were estimated colorimetrically according to methods of Fawcett and $\operatorname{Scott}^{21}$, Bartles et $a l^{22}$, respectively, using aqueous primary standard urea solution $(50 \mathrm{mg} / \mathrm{dl})$, standard creatinine $(2$ $\mathrm{mg} / \mathrm{dl})$.

\section{Evaluation of oxidative stress markers}

Renal content of GSH was assayed according to the method described by Ellman ${ }^{23}$, while Renal thiobarbituric acid reactive substances measured as MDA were assayed according to the method described by Uchiyama and Mihara ${ }^{24}$, using 1,1,3,3tetramethoxypropan as standard.

\section{Estimation of inflammatory markers}

NO was assayed according to the method described by montogomery and dymock ${ }^{25}$. Renal content of COX-2 level was determined using ELISA kit according to the manufacturing instruction based on the principle described by Van Weemen and Schuurs $^{26}$. MPO content was assayed according to the method described by Bradley et al. ${ }^{27}$. Reanal expression of TNF- $\alpha$ was determined by immunhistochemical analysis ${ }^{28}$.

\section{Histopathological examination of the kidney}

Autopsy samples were taken from the kidneys of two rats in different groups and fixed at $10 \%$ neutral buffered formalin for 24 $\mathrm{h}$. Washing was done with distilled water, and then dehydration by serial dilutions of alcohol (methyl, ethyl, and absolute ethyl). Specimens were cleared in xylene and embedded in paraffin at $56^{\circ} \mathrm{C}$ in a hot air oven for $24 \mathrm{~h}$. Paraffin bees wax tissue blocks were prepared for sectioning at $4 \mu \mathrm{m}$ thickness by a sledge microtome. The obtained tissue sections were collected on glass slides, deparaffinized, stained with hematoxylin and eosin, and then an examination was done through the light electric microscope. The blocks were made using paraffin bees wax by sledge microtome, followed by deparaffination and staining by hematoxylin and $\operatorname{eosin}^{28}$.

\section{Immunohistochemical analysis}

Tissue samples were flushed and fixed in $10 \%$ neutral buffered formalin for $72 \mathrm{hrs}$. Samples were trimmed and processed by dehydration in alcohols, clearing in Xylene, synthetic wax infiltration and blocking out into

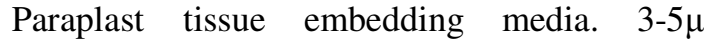
sections were cut by rotatory microtome.

The sections were stained with

1- Harris Hematoxylin and Eosin as a general staining method as Outlined by Bancroft and Stevens (2010).

2- Tumor necrosis factor-alpha immunohistochemical Staining by using rabbit polyclonal antibody RB-9034-R7 From Thermo scientific Co. Expression Area percentage of TNF- $\alpha$ were obtained from (ex. 10 random fields) according to by using a full HD microscopic camera attached to the Leica application suite for immunoexpression analysis (Leica Biosystems- Germany ${ }^{28}$.

\section{Statistical analysis of data}

Data were presented as means \pm standard error of mean (SEM). Statistical analysis was performed using Graph Pad Prism version 5 (Graph pad, San Diego, CA). A comparison between different groups was carried out using one-way analysis of variance (ANOVA), followed by Tukey multiple comparison tests. The difference is considered significant when $P \leq 0.05$.

\section{RESULTS AND DISCUSSION}

\section{Results}

\section{Effect of NAR on kidney functions test}

Data summarized in table 1 show that injection of $\mathrm{CP}$ resulted in a significant increase in serum urea $(280 \%)$ and creatinine (323\%) compared to control group. In contrast, oral administration of NAR significantly reduced the elevated levels of urea and creatinine in serum by $52 \%$ and $61 \%$, respectively in comparison with a murine model. At the end of the experiment the kidney-body weight ratio were significantly increased in rats challenged with $\mathrm{CP}$ respected to control rats. Treatment with NAR significantly reduced kidney-body weight ratio regarded to $\mathrm{CP}$ rats. 
Effect of NAR on oxidative stress biomarkers

Administration of $\mathrm{CP}$ was associated with marked elevation of renal content of MDA $(116 \%)$, while significant reduction in renal contents of GSH (66\%) compared to control group. On the other hand, treatment of rats with NAR resulted in a notable correction of oxidative stress markers as represented in table 2.

\section{NAR effects on inflammatory biomarkers}

Data summarized in table 3 and figure 1 show that CP injection was showed a significant increase in kidney contents of TNF$\alpha$, COX-2 (193\%) and NO (177\%) as well as MPO (244\%) activity in related to control animals. NAR treatment remarkably ameliorated renal contents of TNF- $\alpha, \mathrm{COX}-2$ and NO as well as MPO activity in related to a murine challenged with $\mathrm{CP}$ as illustrated in table 3 .

Effect of treatment with NAR on histopathological findings of kidney tissue in CP-treated rats

Histopathological findings of kidney tissues are illustrated in table 4 and figure 2;

(A) Control saline: shows that normal histological structure of renal parenchyma,

(B) CP-treated group: shows that marked vacuolation (v) and necrosis (n) of renal tubular epithelium as well as periglomerular fibroblasts proliferation $(\mathrm{P})$,

(C) NAR + CP-treated group: shows that slight congestion (c) of glomerular tuft.

Table 1: Effect of treatment with NAR on serum urea, creatinine and kidney-body weight ratio in CP-treated rats.

\begin{tabular}{|c|c|c|c|}
\hline Groups & $\begin{array}{c}\text { Urea } \\
(\mathrm{mg} / \mathrm{dl})\end{array}$ & $\begin{array}{c}\text { Creatinine } \\
(\mathrm{mg} / \mathrm{dl})\end{array}$ & $\begin{array}{c}\text { Kidney-Body } \\
\text { Weight ratio } \\
(1000 \times)\end{array}$ \\
\hline Control saline & $30.50 \pm 2.95$ & $0.92 \pm 0.077$ & $5.6 \pm 0.29$ \\
\hline $\mathrm{CP}$ & $114 \pm 5.71^{\mathrm{a}}$ & $3.9 \pm 0.14^{\mathrm{a}}$ & $13.85 \pm 0.0^{\mathrm{a}}$ \\
\hline $\mathrm{CP}+\mathrm{NAR}$ & $72.75 \pm 5.93^{\mathrm{a}, \mathrm{b}}$ & $1.81 \pm 0.102^{\mathrm{a}, \mathrm{b}}$ & $9.45 \pm 0.3^{\mathrm{a}, \mathrm{b}}$ \\
\hline
\end{tabular}

Data are expressed as mean \pm SEM of eight rats per group.

${ }^{a}$ Significantly different from the control saline group.

${ }^{\mathrm{b}}$ Significantly different from the CP-treated group.

ANOVA followed by the Tukey-Kramer test for multiple comparison at $p \leq 0.05$.

Table 2: Effect of treatment with NAR on kidney contents of MDA and GSH in CP-treated rats.

\begin{tabular}{|c|c|c||}
\hline $\begin{array}{c}\text { Parameters } \\
\text { Group }\end{array}$ & $\begin{array}{c}\text { MDA } \\
(\mathrm{nmol} / \mathrm{g} \text { Tissue })\end{array}$ & $\begin{array}{c}\text { GSH } \\
(\mu \mathrm{mol} / \mathrm{g} \text { tissue })\end{array}$ \\
\hline Control Saline & $20.75 \pm 1.54$ & $8.97 \pm 0.319$ \\
\hline $\mathrm{CP}$ & $44.5 \pm 2.84^{\mathrm{a}}$ & $3.025 \pm 0.213^{\mathrm{a}}$ \\
\hline $\mathrm{CP}+\mathrm{NAR}$ & $28.75 \pm 2.016^{\mathrm{b}}$ & $7.47 \pm 0.311^{\mathrm{a}, \mathrm{b}}$ \\
\hline
\end{tabular}

Data are expressed as mean \pm SEM of six rats per group.

${ }^{a}$ Significantly different from the control saline group.

${ }^{\mathrm{b}}$ Significantly different from the CP-treated group

Table 3: Effect of treatment with NAR on inflammatory biomarkers in CP-treated rats.

\begin{tabular}{||c|c|c|c|c||}
\hline $\begin{array}{c}\text { Parameters } \\
\text { Group }\end{array}$ & $\begin{array}{c}\text { COX-2 } \\
(\mathrm{pg} / \mathrm{ml})\end{array}$ & $\begin{array}{c}\text { MPO } \\
(\mathrm{U} / \mathrm{g} \text { tissue })\end{array}$ & $\begin{array}{c}\text { NO } \\
(\mu \mathrm{mol} / \mathrm{g} \text { tissue })\end{array}$ & $\begin{array}{c}\text { TNF- } \alpha \\
\text { Area\% }\end{array}$ \\
\hline Control Saline & $45 \pm 2.95$ & $10.98 \pm 0.833$ & $2.37 \pm 0.228$ & $0.750 \pm .064$ \\
\hline CP & $132.4 \pm 3.77^{\mathrm{a}}$ & $37.8 \pm 1.93^{\mathrm{a}}$ & $6.57 \pm 0.268^{\mathrm{a}}$ & $41.5 \pm 1.93^{\mathrm{a}}$ \\
\hline CP + NAR & $84.75 \pm 2.64^{\mathrm{a}, \mathrm{b}}$ & $22 \pm 2^{\mathrm{b}}$ & $3.87 \pm 0.149^{\mathrm{b}}$ & $22 \pm 2^{\mathrm{a}, \mathrm{b}}$ \\
\hline
\end{tabular}

Data are expressed as mean \pm SEM of six rats per group.

${ }^{\text {a }}$ Significantly different from the control saline group.

${ }^{\mathrm{b}}$ Significantly different from the CP-treated group. 

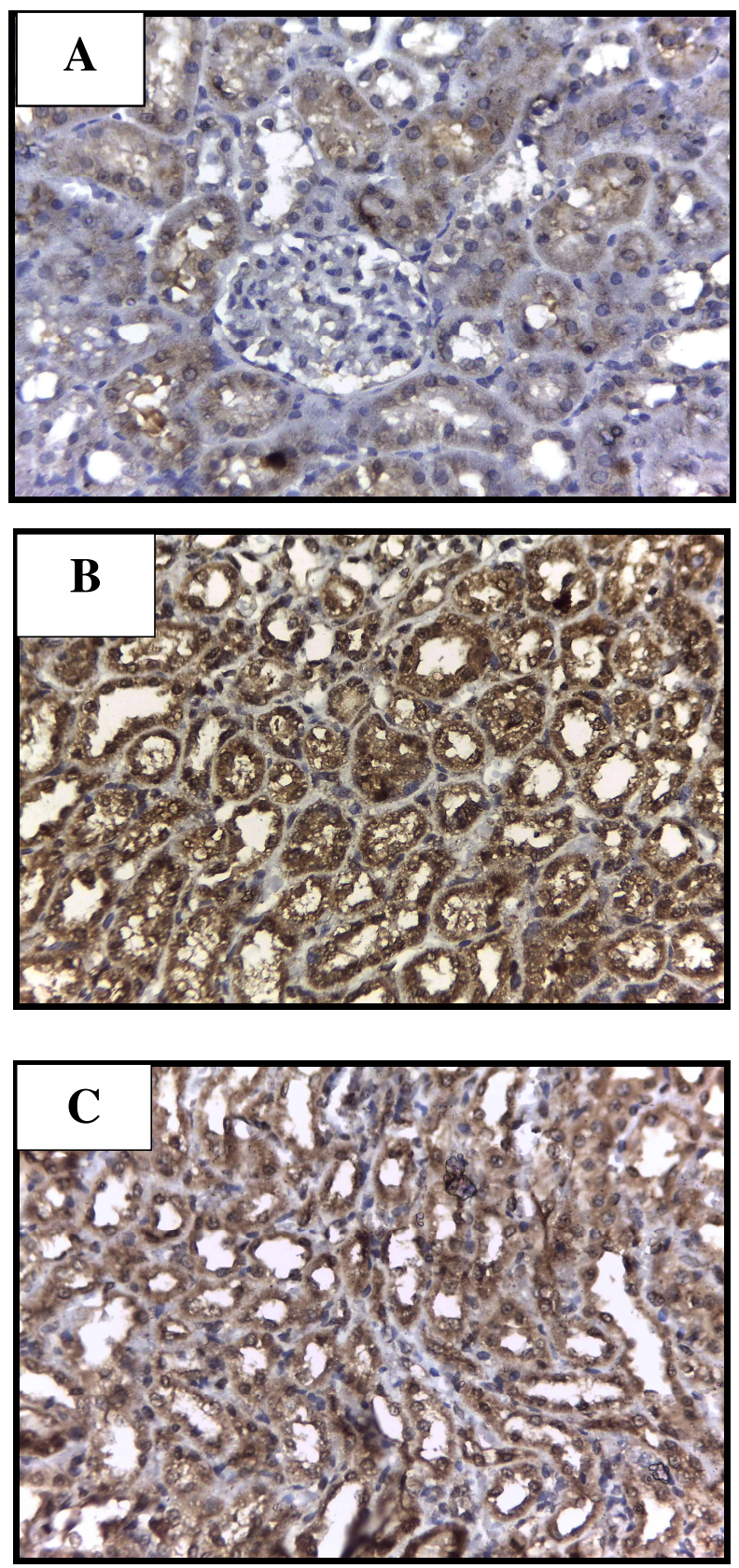

Fig. 1: Immunohistochemical assay of TNF- $\alpha$ in CP-treated rats: A: Normal control group

$\mathrm{B}$ : CP- treated group

$\mathrm{C}$ : NAR+CP treated group 
Table 4: Effect of treatment with NAR on histopathological findings of kidney tissues of cisplatintreated rats.

\begin{tabular}{|c|c|c|c|}
\hline Groups & Conrtol Saline & $\mathrm{CP}$ & $\mathrm{NAR}+\mathrm{CP}$ \\
\hline $\begin{array}{l}\text { Vacuolation of renal tubular } \\
\text { epithelium and glomerular tufts }\end{array}$ & - & +++ & + \\
\hline Congestion of glomerular tufts & _ & ++ & + \\
\hline $\begin{array}{c}\text { Cystic dilatation of renal } \\
\text { tubules }\end{array}$ & - & +++ & - \\
\hline $\begin{array}{c}\text { Necrosis of renal tubular } \\
\text { epithelium }\end{array}$ & - & ++ & + \\
\hline $\begin{array}{l}\text { Cellular cast in the lumen of } \\
\text { renal tubules }\end{array}$ & - & ++ & - \\
\hline Chronic interstitial nephritis & _ & +++ & _ \\
\hline
\end{tabular}
(-) normal
(+) milde
$(++)$ moderate
$(+++)$ sever
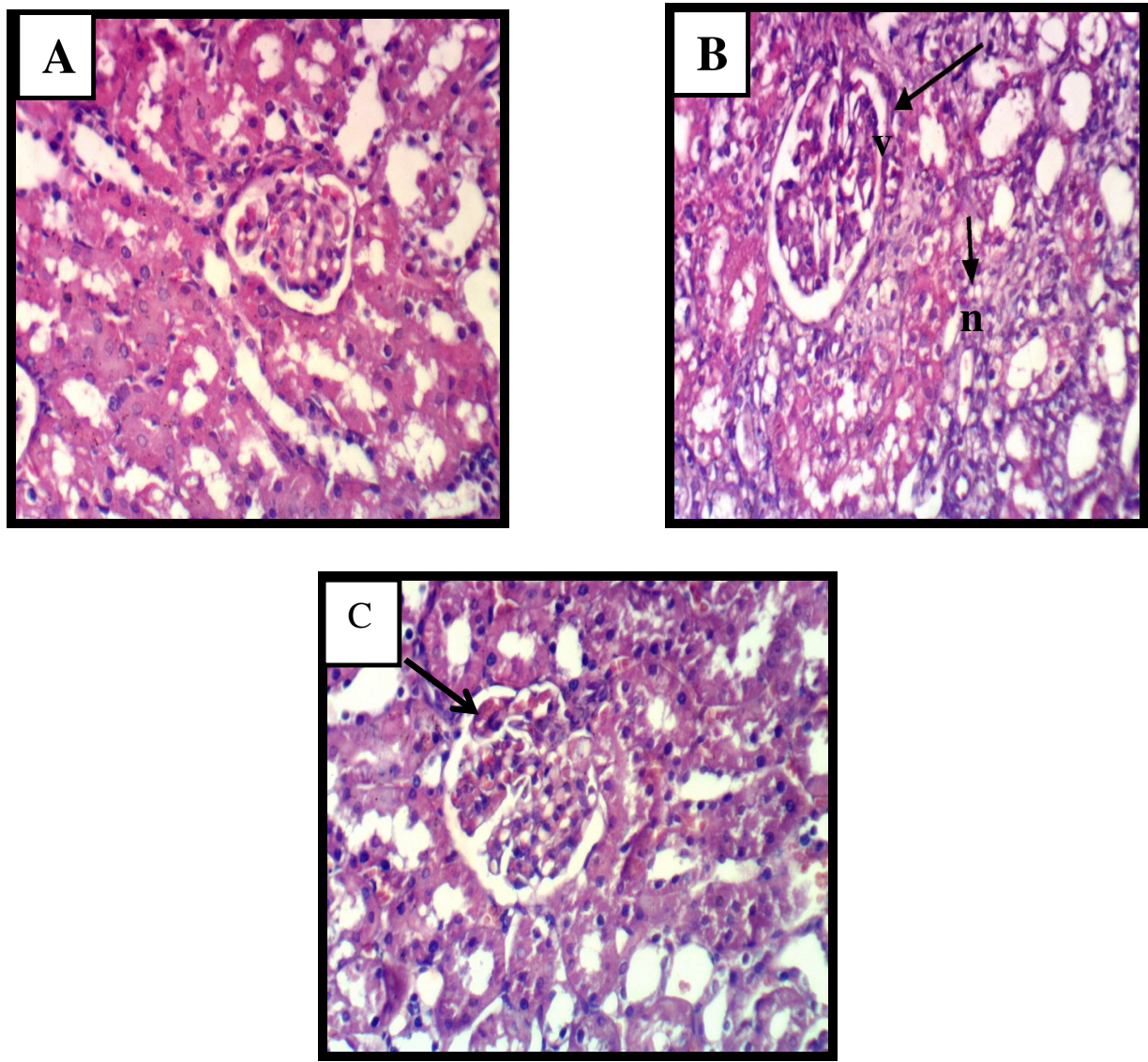

Fig. 2: Effect of Treatment with NAR on Histopathological Findings of Kidney Tissues of CP-Treated Rats

(A) control saline: shows that normal histological structure of renal parenchyma,

(B) CP-treated group: shows that marked vacuolation (v) and necrosis (n) of renal tubular epithelium as well as periglomerular fibroblast proliferation,

(C) NAR + CP-treated group: shows that slight congestion (c) of glomerular tuft. 


\section{Discussion}

Nephrotoxicity remains the most complicating factor of $\mathrm{CP}$ used in chemotherapy that might be attributed to $\mathrm{CP}$ induced oxidative injury, free radical generation and its direct accumulative effect in renal tissues ${ }^{10}$. Many researches have established the ability of antioxidants of natural origin to protect against pathological conditions induced via chemotherapeutic agents. Many researches had been demonstrated that NAR has antioxidant, antiiflammatory and anti-apoptotic activities ${ }^{16}$.

Therefore, the present study was designed to evaluate the possible protective effects of NAR against CP-induced nephrotoxicity in rats. Our results revealed that $\mathrm{CP}$-induced renal injury manifested by a significant elevation in serum creatinine, urea, and kidney-body weight ratio accompanied with a experiment ${ }^{10}$. These abnormalities could be attributed to reduction in glomerular filteration rate, increase in glomerular volume and cellular degenerative changes. As well as, gastrointestinal toxicity evidenced by severe body weight reduction ${ }^{8}$.

Morevere, our data showed that a single dose of $\mathrm{CP}$ has the ability to produce severe changes in oxidative stress parameters confirmed by a significant increase in renal contents of MDA and NO with a significant reduction in GSH levels in the tissue. Additionally, increased renal NO production may induce cellular injury as was confirmed, NO reacts with superoxide anion to generate peroxynitrite radical, a potent prooxidant and cytotoxic intermediate that causes protein nitration and tissue injury. Also, excess NO depletes intracellular GSH thus increasing the susceptibility to oxidative stress ${ }^{1}$. These results are consistent with de Oliveira Mora et al., 2003 and Shimeda et al., 2005 $5^{29 \& 30}$ who found that CP generates a large amount of ROS includes superoxide anion, hydrogen peroxide, and hydroxyl radicals which, induces lipid peroxidation causing an oxidative damage in renal cells and tubular atrophy as well as, depletion of endogenous antioxidants.

Furthermore, our study revealed that $\mathrm{CP}$ cause inflammation of renal tubules manifested by of a significant elevation in renal contents of inflammatory biomarker, COX-2, TNF- $\alpha$ and MPO activity which is a marker of neutrophil infiltration via induction of oxidative stress cascade that triggers an immune response and mediates inflammation in renal tissue ${ }^{31,32 \& 33}$.

On the other hand, the present study revealed that oral treatment of rats with NAR ameliorates CP-induced alterations in serum levels of creatinine, urea, body weight and kidney-body weight ratio ${ }^{19}$. In addition to, it is significantly mitigates the lipid peroxidation measured by a significant decrease in renal content of MDA, and NO as well as, it cause a significant improvement in the GSH levels. These results could be attributed to the potential antioxidant effect of $\mathrm{NAR}^{34}$.

Also, our data showed that NAR treatment obviously mitigated CP-induced renal inflammation via a significant decrease in the renal contents of COX-2, TNF- $\alpha$ and MPO. NAR was found to reduce the level of MPO in a dose dependent manner. The inhibition of neutrophil infiltration in renal tissue by naringin is also evident in the histopathological observations of renal tissue. The reversal of neutrophil infiltration by NAR established its anti-inflammatory activity ${ }^{32}$. This finding is consistent with Chtourou et $a l^{17}$, who demonstrated that NAR has antioxidant, antiinflammatory and anti-apoptotic activities. Furthermore, our histopathological findings demonstrated that administration of CP produced various degenerative changes in kidney cells which confirmed the biochemical evidence of the oxidative stress. In contrast, the treatment with NAR obviously mitigated the histopathological changes induced by $\mathrm{CP}^{35}$.

\section{Conclusion}

The present study revealed the nephroprotective effect of NAR against CPinduced renal injury by abrogation of oxidative stress, inflammation which might be attributed to their antioxidant, anti-inflammatory effect.

\section{REFERNCES}

1- N. Pabla and Z. Dong, "Cisplatin nephrotoxicity: Mechanisms and renoprotective strategies", Kidney Inter., 73, 994-1007 (2008).

2- C. A. Naughton, "Drug-induced nephrotoxicity", Am. Fam. Physician, 78 (2008).

3- S. Y. Kim and A. Moon, "Drug-induced nephrotoxicity and its biomarkers", Biomol. Ther. (Seoul), 20, 268 (2012). 
4- M. A. Perazella and G. W. Moeckel, "Nephrotoxicity from Chemotherapeutic Agents: Clinical Manifestations, Pathobiology, and Prevention/Therapy", In: Semin. Nephrol. , Elsevier, 2010, pp. 570-581.

5- X. Yao, K. Panichpisal, N. Kurtzman and K. Nugent, "Cisplatin nephrotoxicity: A review", Am. J. Med. Sci., 334, 115-124 (2007).

6- B. H. Ali and M. S. Al Moundhri, "Agents ameliorating or augmenting the nephrotoxicity of cisplatin and other platinum compounds: A review of some recent research", Food Chem. Toxicol., 44, 1173-1183 (2006).

7- J. C. Gautier, B. Riefke, J. Walter, P. Kurth, L. Mylecraine, V. Guilpin, N. Barlow, T. Gury, D. Hoffman and D. Ennulat, "Evaluation of novel biomarkers of nephrotoxicity in two strains of rat treated with Cisplatin", Toxicol. Pathol., 38, 943-956 (2010).

8- M. A. Ferguson, V. S. Vaidya and J. V. Bonventre, "Biomarkers of nephrotoxic acute kidney injury", Toxicology, 245, 182-193 (2008).

9- C. A. Davis, H. S. Nick and A. Agarwal, "Manganese superoxide dismutase attenuates cisplatin-induced renal injury: Importance of superoxide", J. Am. Soc. Nephrol., 12, 2683-2690 (2001).

10- R. P. Miller, R. K. Tadagavadi, G. Ramesh and W. B. Reeves, "Mechanisms of cisplatin nephrotoxicity", Toxins (Basel), 2, 2490-2518 (2010).

11- R. Domitrović, O. Cvijanović, E. PernjakPugel, M. Škoda, L. Mikelić and Ž. Crnčević-Orlić, "Berberine exerts nephroprotective effect against cisplatininduced kidney damage through inhibition of oxidative/nitrosative stress, inflammation, autophagy and apoptosis", Food Chem. Toxicol., 62, 397-406 (2013).

12- B. S. Cummings and R. G. Schnellmann, "Cisplatin-induced renal cell apoptosis: Caspase 3-dependent and-independent pathways", J. Pharmacol. Exper. Ther., 302, 8-17 (2002).

13- M. Adil, A. Visnagri, V. S. Kumar, A. D. Kandhare, P. Ghosh and S. Bodhankar, "Protective effect of naringin on sodium arsenite induced testicular toxicity via modulation of biochemical perturbations in experimental rats", Pharmacologia, 5, e234 (2014).

14- H. J. Kim, J. Y. Song, H. J. Park, H. K. Park, D. H. Yun and J. H. Chung, "Naringin protects against rotenoneinduced apoptosis in human neuroblastoma SH-SY5Y cells", Korean J. Physiol. Pharmacol., 13, 281-285 (2009).

15- S. C. Choe, H. S. Kim, T. -S. Jeong, S. H. Bok and Y. B. Park, "Naringin has an antiatherogenic effect with the inhibition of intercellular adhesion molecule-1 in hypercholesterolemic rabbits", $\boldsymbol{J}$. Cardiovasc. Pharmacol., 38 947-955 (2001).

16- M. Rajadurai and P. Prince, "Naringin ameliorates mitochondrial lipid peroxides, antioxidants and lipids in isoproterenolinduced myocardial infarction in Wistar rats", Phytother. Res., 23, 358-362 (2009).

17- Y. Chtourou, B. Aouey, M. Kebieche and H. Fetoui, "Protective role of naringin against cisplatin induced oxidative stress, inflammatory response and apoptosis in rat striatum via suppressing ROSmediated NF- $\kappa \mathrm{B}$ and P53 signaling pathways", Chem. Biol. Interact., 239, 76-86 (2015).

18- A. Atessahin, S. Yilmaz, I. Karahan, A. O. Ceribasi and A. Karaoglu, "Effects of lycopene against cisplatin-induced nephrotoxicity and oxidative stress in rats", Toxicology, 212, 116-123 (2005).

19- Y. Chen, Y. C. Nie, Y. 1. Luo, F. Lin, Y. F. Zheng, G. H. Cheng, H. Wu, K. J. Zhang, W. W. Su and J. G. Shen, "Protective effects of naringin against paraquat-induced acute lung injury and pulmonary fibrosis in mice", Food Chem. Toxicol., 58, 133-140 (2013).

20- N. R. Council, "Guide for the care and use of laboratory animals". Institute of Laboratory Animal Resources, Commission on Life Sciences, National Academy of Sciences, Washington, DC, (1996).

21- J. Fawcett and J. Scott, "A rapid and precise method for the determination of 
urea", J. Clin. Pathol., 13, 156-159 (1960).

22- C. Kammeraat, "Modification of the alkaline picrate assay for creatinine to prevent spuriously elevated values by keto acids", Clin. Chim. Acta., 84, 119-128 (1978).

23- G. L. Ellman, "Tissue sulfhydryl groups", Arch. Biochem. Biophys., 82, 70-77 (1959).

24- M. Uchiyama and M. Mihara, "Determination of malonaldehyde precursor in tissues by thiobarbituric acid test", AnBio, 86, 271-278 (1978).

25- H. Montogomery and J. Dymock, "The determination of nitrite in water: Colorimetric method of nitric oxide assay", Analyst, 86, 414 (1961).

26- B. Van Weemen and A. Schuurs, "Immunoassay using antigen-enzyme conjugates", FEBS Lett., 15, 232-236 (1971).

27- P. P. Bradley, D. A. Priebat, R. D. Christensen and G. Rothstein, "Measurement of cutaneous inflammation: Estimation of neutrophil content with an enzyme marker", J. Invest. Dermatol., 78, 206-209 (1982).

28- J. Banchroft, A. Stevens and D. Turner, "Theory and Practice of Histological Technique" Fourth Edition, Churchill Livingstone, New York, London, San Francisco, Tokyo, (1996).

29- Y. Shimeda, Y. Hirotani, Y. Akimoto, K. Shindou, Y. Ijiri, T. Nishihori and K. Tanaka, "Protective effects of capsaicin against cisplatin-induced nephrotoxicity in rats", Biol. Pharma. Bull., 28, 1635-1638 (2005).
30- L. de Oliveira Mora, L. M. G. Antunes and M. d. L. P. Bianchi, "The effects of oral glutamine on cisplatin-induced nephrotoxicity in rats", Pharmacol. Res., 47, 517-522 (2003).

31- K. P. Kang, D. H. Kim, Y. J. Jung, A. S. Lee, S. Lee, S. Y. Lee, K. Y. Jang, M. J. Sung, S. K. Park and W. Kim, "Alphalipoic acid attenuates cisplatin-induced acute kidney injury in mice by suppressing renal inflammation", Nephrol. Dial. Transplant., 24, 30123020 (2009).

32- V. S. Kumar, A. R. Rajmane, M. Adil, A. D. Kandhare, P. Ghosh and S. L. Bodhankar, "Naringin ameliorates acetic acid induced colitis through modulation of endogenous oxido-nitrosative balance and DNA damage in rats", J. Biomed. Res., 28, 132 (2014).

33- M. Ueki, M. Ueno, J. Morishita and N. Maekawa, "Curcumin ameliorates cisplatin-induced nephrotoxicity by inhibiting renal inflammation in mice", $\boldsymbol{J}$. Biosci. Bioeng., 115, 547-551 (2013).

34- G. C. Jagetia and T. K. Reddy, "Alleviation of iron induced oxidative stress by the grape fruit flavanone naringin in-vitro", Chem. Biol. Interact., 190, 121-128 (2011).

35- O. Benavente-Garcia and J. Castillo, "Update on uses and properties of citrus flavonoids: new findings in anticancer, cardiovascular, and anti-inflammatory activity", J. Agr. Food Chem., 56, 61856205 (2008). 
Bull. Pharm. Sci., Assiut University, Vol. 41, 2018, pp. 45-54.

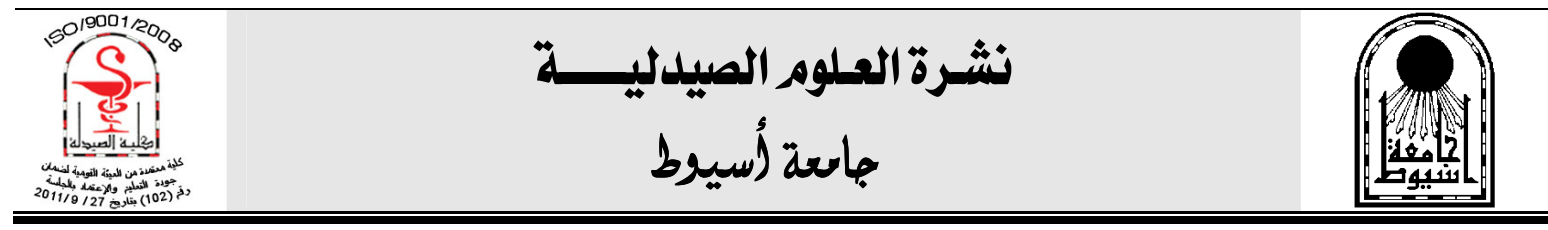

\section{النارينجين يمنع السميه الكلوية المستحثة بالسيسبلاهين بواسطة الحد من الأكسدة

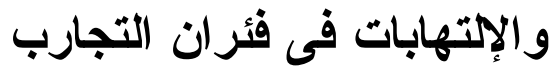

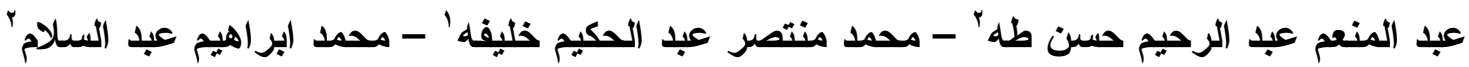
'قسم الأدويه والسموم ، كلية الصيدلة ، جامعة المنيا ، مصر

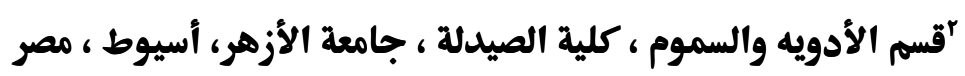

التسمم الكلوي يظل أحد أهم التأثيرات الضارة لاستخدام عقار السيسبلاتين فــي عــلاج الأورام

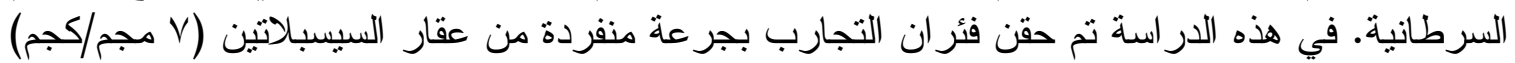

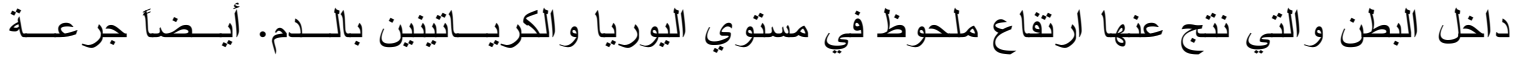

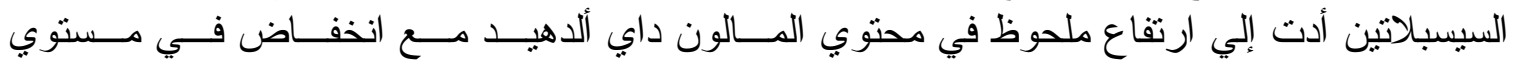

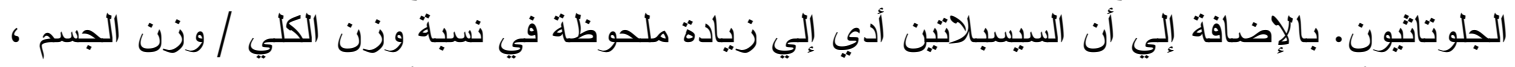

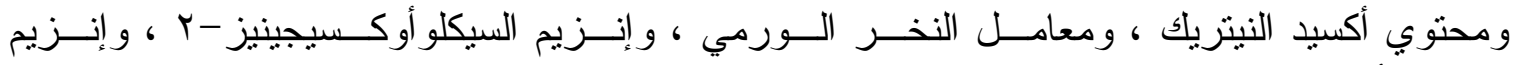

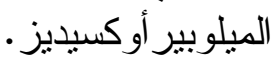
التحليل الظاهري للأنسجة الكلوية يؤكد نتائج التحليل البيوكيميائي و الجزيئي و الذي أظهر تغيير في الأنسجة الكلوية عقب حقن جرعة الطان الحدة من السيسبلاتين.

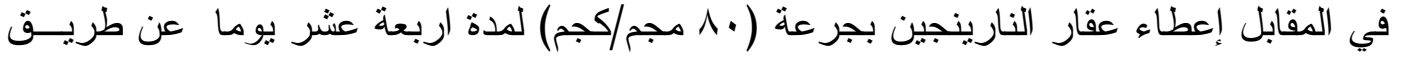

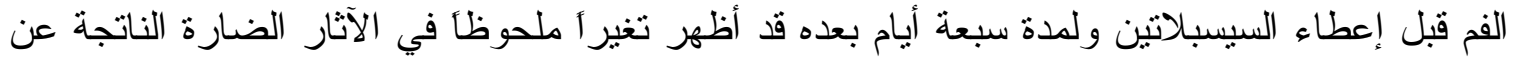

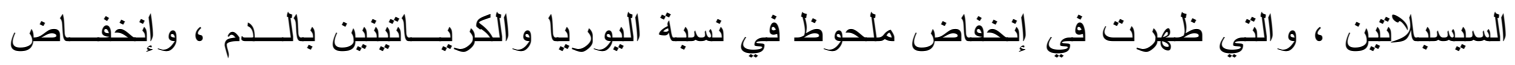

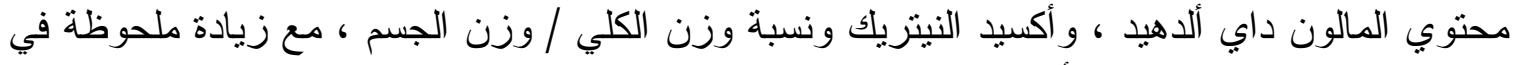
محتوي الجلو تاثيون كمضاد للأكسدة.

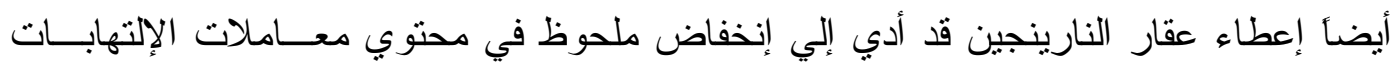

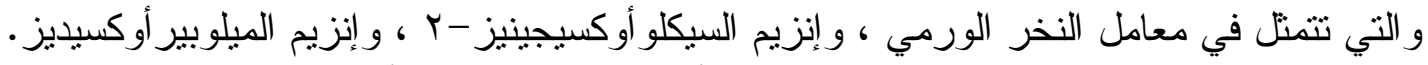

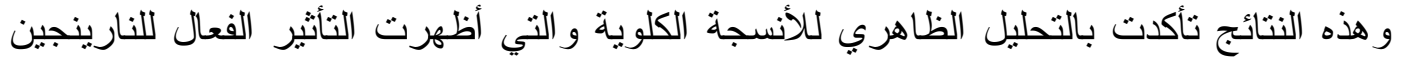
في الحماية ضد السمية الكلوية المستحثة بالسيسبلاتين. 